\title{
NOTES ON NEW WORLD HIPPOCRATEEAE (FAM. CELASTRACEAE) II. A NEW SPECIES IN HEMIANGIUM
}

\author{
A.M. W. MENNEGA
}

Instituut voor Systematische Plantkunde, Postbus $80.102,3508$ TC Utrecht

\section{SUMMARY}

Anthodus paniculatus Martius, reduced to a synonym of Hemiangium excelsum (H.B.K.) A. C. Smith by A. C. Smith, is reestablished here as Hemiangium paniculatum (Mart.) A. M. W. Mennega. $H$. excelsum in the present sense is now restricted to C. America, whereas $H$. paniculatum occurs in S. America.

In his treatment of the New World Hippocrateaceae A. C. SMITH (1940) created the new monotypic genus Hemiangium. This genus was based on a plant collected by Humboldt and Bonpland near Mazatlan, Guerrero, Mexico. It was first described by Kunth as Hippocratea excelsa in H. B. K. Nov. Gen. et Sp. (1822). In the same year but a few months later, a plant collected by Martius in the vicinity of Rio de Janeiro was published by Schultes in Roemer \& Schultes' Mantissa (1822) as Anthodus paniculatus Mart., with a note "Martius in litt.", probably referring to the annotation by Martius on the type sheet in the herbarium of Brussels (BR). Both descriptions were brief.

Lateron PEYRITSCH (1878) included this Martius collection in the genus Salacia as S. paniculata (Mart.) Peyr. His decision to transfer this taxon from Anthodus to Salacia probably was based on the shape of the disk which is suggestive of Salacia, but if he had known the fruits that are compound of three basically and laterally connate capsules, he might have retained the taxon in Anthodus.

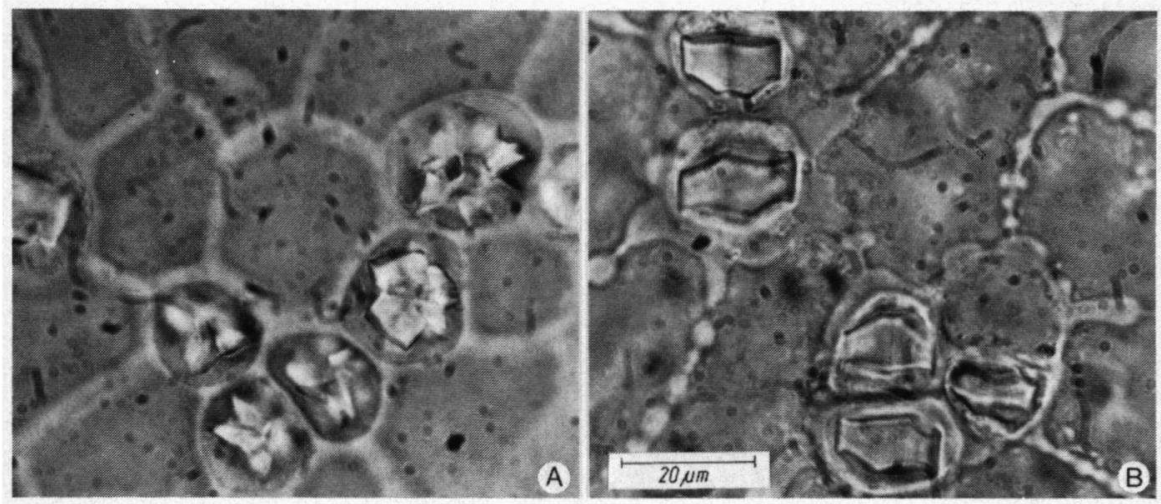

Plate 1. A. Leaves of

B. Leaves of . 
SMITH (1940) concluded that the numerous collections from Mexico and Central America and the few specimens from Colombia and Venezuela identified as Hippocratea excelsa and several other species of Hippocratea (all listed as synonyms by Smith) were identical with specimens from the Rio de Janeiro region referred to Salacia paniculata (Mart.) Peyr. He included all of them in $\mathrm{He}$ miangium and in his opinion Hemangium excelsum (H.B.K.) A. C. Smith became the only species in the genus.

The geographical distribution of the species is unusual as Smith rightly remarked. He cited specimens from Mexico, Central America, Colombia, Venezuela, South Brazil and Paraguay. From the material I have at hand it appears that collections have become more numerous, but chiefly from the Mexican and Central American regions. Though Smith was struck by the large geographical gap between the regions, he wrote, that he "failed to find any characters which would serve to remove southern specimens from those of the north", adding "that perhaps finer criteria will permit division".

As a mattter of fact one such "finer criterium" has now been revealed by leaf anatomical study. DEN HARTOG \& BAAS (1978) in their treatment of the leaf anatomical studies of the Celastraceae s.l. referred to the occurrence of small crystalliferous cells containing rhomboidal crystals in Hemiangium excelsum. They observed those in a specimen collected in Paraguay (Woolston 1161, U). When I myself studied the leaf structure of a specimen of $H$. excelsum from Nicaragua, I was surprised to find druses in several epidermal cells instead of rhomboidal crystals. Further observations on leaves of material from both Central and South America showed that the 13 specimens studied from the former region had druses in their epidermal and sub-epidermal cells, and that in the 8 specimens from the latter region rhomboidal crystals occurred (plate l).
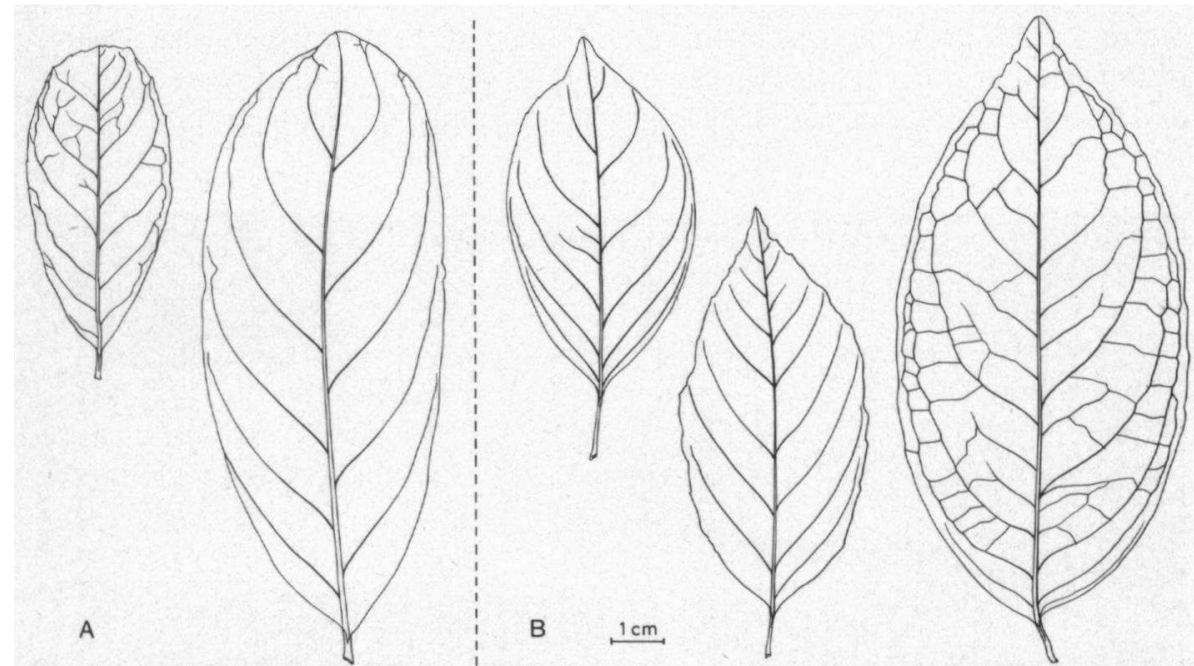

Plate 2. Crystal types in the epidermal cells of Hemiangium. A. Druses in H. excelsum; B. Rhomboidal crystals in $\boldsymbol{H}$. paniculatum. 
Table 1.

\begin{tabular}{lll}
\hline & H.excelsum & H.paniculatum \\
\hline Petioles: & $\begin{array}{l}\text { Rather thick, 2-7-(10) mm long } \\
\text { Leaves: }\end{array}$ & $\begin{array}{l}\text { Slender, (7)-10-14 mm long } \\
\text { thinly coriaceous }\end{array}$ \\
Epidermal crystals: & $\begin{array}{l}\text { Druses } \\
\text { Always present, but in varying den- } \\
\text { Indumentum: } \\
\text { sity and quantity }\end{array}$ & $\begin{array}{l}\text { Elliptic; the tip acute to acuminate; } \\
\text { chartaceous }\end{array}$ \\
Flower colour: & $\begin{array}{l}\text { Greenish yellow, pale green or green, } \\
\text { the base of the petals white }\end{array}$ & $\begin{array}{l}\text { Yellow, exceptionally greenish yel- } \\
\text { low }\end{array}$ \\
Distribution: & Central America and Mexico & South America \\
\hline
\end{tabular}

This anatomical feature is not easily seen as it involves bleaching of a piece of leaf and examination under the microscope. However, other more obvious morphological differences are also present between the specimens from Central and South America. These distinguishing characters as well as the geographical distribution are listed in table 1. Most important among these morphological differences are the leaf shape, obovate versus elliptic, and the rounded leaf tip versus the acuminate tip (plate 2). The presence or absence of hairs is also a constant character, though the degree of hairiness varies from densely tomentose on branches, leaves, and inflorescences to hairy on bud scales and branchlets of the inflorescences; yet some hairs can always be found on material of Central American origin, whereas in Hemiangium from South America hairs are completely absent.

This complex of differing characters convinced me that the specimens of $\mathrm{He}$ miangium should be accomodated into two different species. The plants from South America are therefore transferred to Hemiangium paniculatum (Mart.) A. M. W. Mennega comb. nov. Basionym: Anthodus paniculatus Martius ex Schultes in Roemer \& Schultes, 1822. Mantissa 1: 348.

The geographical distribution of both species is shown in plate 3. Hemiangium excelsum is apparently of common occurrence in Southern Mexico and Central America. Collections of $H$. paniculatum are still scarce. Additional collections are now known from Southern and Central Brazil, also one from the neighbourhood of Bahia (Mori et al. 14415), but no recent material is known to me from either Colombia or Venezuela. The Columbian locality, Porto Colombia (Elias, 1210), and the Venezuelan locality, Colonia Tovar (Fendler, 197 and 1048) are both situated in the Northern, Caribbean part of the countries, therefore I had expected that these specimens might belong to H. excelsum. However, investigation of the leaves revealed the presence of rhombic crystals in the epidermal cells. Leaf shape and length of the petioles also pointed at $H$. paniculatum.

At present the geographical distribution of Hemiangium paniculatum is confined to South America where it occurs in two disjunct areas.

A final remark concerns Hippocratea bilobicarpa Miers, considered by Smith as a synonym of Hemiangium excelsum; this is based on a specimen collected 


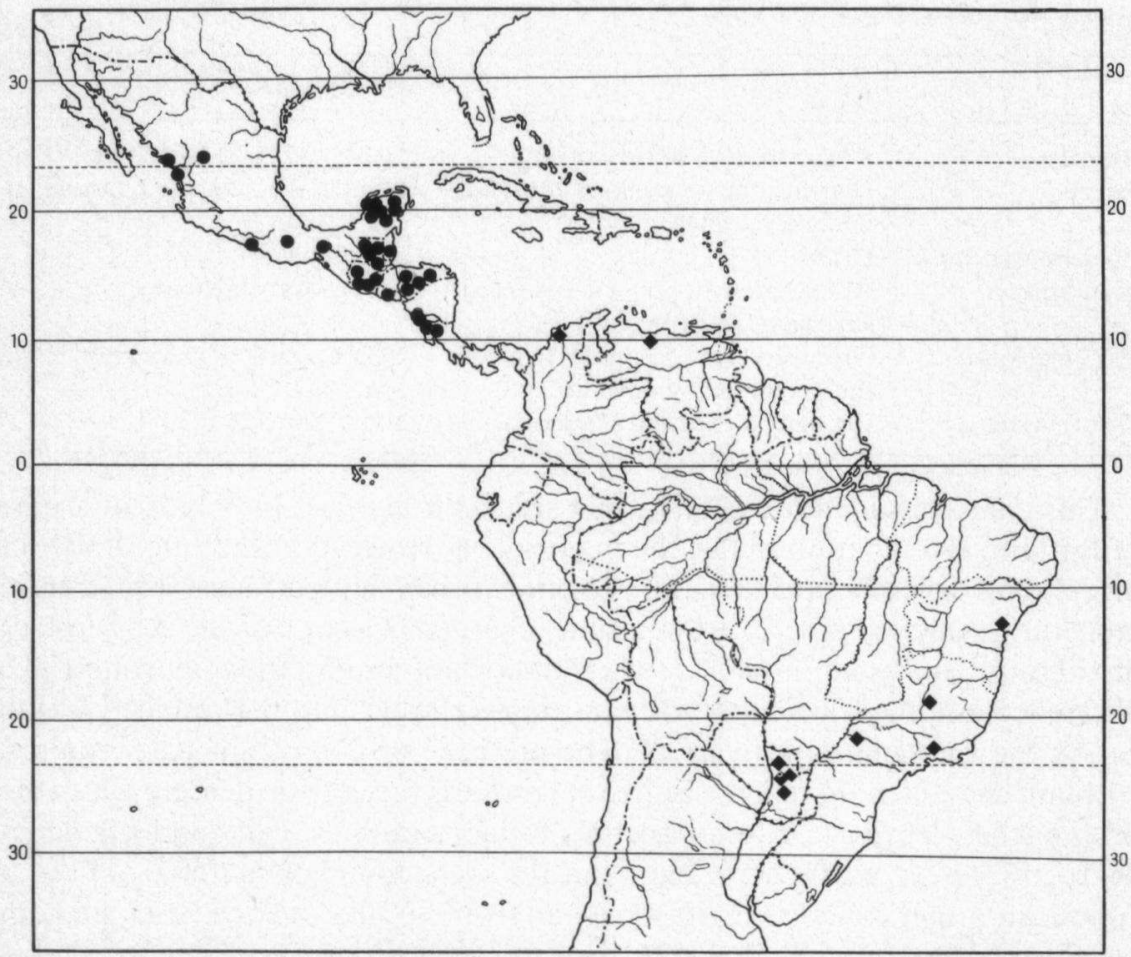

Plate 3. Distribution map of Hemiangium. Dots: H. excelsum; Squares: H. paniculatum.

by Miers at Pertiningui (prov. Rio de Janeiro). This locality would suggest a specimen of $H$. paniculatum, but the type material, which I could investigate was so poor (no leaves) that identification was not possible.

\section{ACKNOWLEDGEMENTS}

The loan of material by Curators of the following herbaria is gratefully acknowledged: $\mathrm{Br}, \mathrm{F}, \mathrm{G}$, K, MO, P. The author is much indebted to Drs. L. Y. Th. Westra for his critical remarks and for correction of the English text.

\section{REFERENCES}

HARTOG, née van TER THOLEN, R. M. DEN \& P. BAas(1978): Epidermal characters of the Celastraceae sensu lato. Acta Bot. Neerl. 27: 355-388.

Humboldt, F. A. von, A. BonPLAND \& K. S. Kunth (1822): Hippocrateaceae. Nov. Gen. et Spec. 5: $136-140$.

Miers, J. (1872): On the Hippocrateaceae of South America. Trans. Linn. Soc. 28: 349.

Peyritsch, J. (1878): Hippocrateaceae. In Martius Flor. Bras. 11(1): 155.

SChultes, J. A. (1822) in Roemer \& Schultes Syst. Veg. Mantissa I: 346.

SMITH, A. C. (1940): The American species of Hippocrateaceae. Brittonia 3: 41 1-417. 